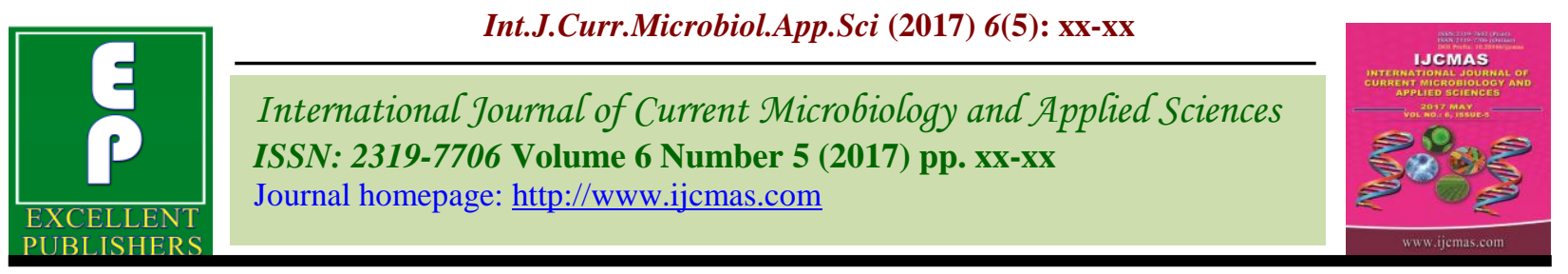

Original Research Article

https://doi.org/10.20546/ijcmas.2017.605.237

\title{
Carbon Sequestration and Soil Properties Changes on Growth and Yield of Simarouba (Simarouba glauca d.c.) based Agroforestry System Under North Gujarat Agro Climatic Conditions
}

\author{
Narendra Kumar Bajdoliya, R.R. Shakhela and M.K. Man* \\ Department of Agricultural Chemistry and Soil Science, Sardarkrushinagar Dantiwada \\ Agricultural University Sardarkrushinagar - 385 506, India \\ *Corresponding author
}

\author{
A B S T R A C T
}

\begin{tabular}{|l|}
\hline Ke y w o r d s \\
Agroforestry, \\
$\begin{array}{l}\text { Simarouba, } \\
\text { Mustard, } \\
\text { Yield }\end{array}$ \\
\hline Article Info \\
\hline $\begin{array}{l}\text { Accepted: } \\
\text { 19 April } 2017 \\
\text { Available Online: } \\
\text { 10 May } 2017\end{array}$ \\
\hline
\end{tabular}

A field experiment was conducted at Research Farm, Centre for Agroforestry Forage Crops and Green Belt, S. D. Agricultural University, Sardarkrushinagar, (Gujarat) in a randomized block design during the Rabi season of 2010-11. The soil of the experimental field was low in nitrogen, medium in available phosphate and potash and alkaline (7.82) in reaction. The maximum plant height at 60 DAS and at harvest, branches plant-1, siliqua plant-1, test weight, seed, stover and total biomass yield of mustard as intercrop (1924.00, 4760.50 and $6684.50 \mathrm{~kg}$ ha-1) and higher oil content $(39.91 \%)$ and oil yield (768.05 kg ha1) were registered under the treatment of mustard sole with $100 \%$ RDF. But In simarouba tree maximum height, collar diameter, diameter at breast height, fresh and dry fruit weight (2221. 91 and $902.70 \mathrm{~kg}$ ha-1), above, below and total ground level weight in $\mathrm{kg}$ tree-1 $(112.12,22.42$ and $134.54 \mathrm{~kg}$ tree-1) and tha-1 (46.72, 9.34 and $56.06 \mathrm{t}$ ha-1), oil content $(56.57 \%)$ and oil yield $(514.67 \mathrm{~kg}$ ha-1) noted under simarouba + mustard with $100 \%$ RDF.

\section{Introduction}

Agroforestry is a dynamic ecologically sound natural resource conserving practice that, through the integration of trees on agricultural landscape, diversifies and sustains production for increase social, economic and environment benefits. Agrisilviculture is the combination of forestry trees and the field crops. Agroforestry is the successful management of resources to satisfy changing human needs while, maintaining or enhancing the quality of the environment and conserving the natural resources. Agroforestry is a collective name for all land system practices where woody perennials are deliberately grown on the same land unit of agricultural crops. Agroforestry system can be biological more productive than either pure crop or pure trees systems provided that trees and crops are partially complement an in use of growth resources. Interaction of woody perennials with annual crop into farming systems leads to greater prosperity at the farm level.

Agriculture is sustainable when it is in harmony with the natural cycles, especial those of Carbon, Nitrogen, water and energy. Conserving them together in biomass of plants and soil organic matter should be the 
goal of sustainable farming. Agroforestry systems are sustainable approach for land use management to get the maximum benefit of the natural resources. Soil health management is based on soil fertility management, selection of suitable tree and crop component and minimization of competitive interaction. Assessment of soil health is essential for determining the ecosystem functioning stability and sustainability of land use in place. The decomposition of litter fall added through trees species affect the soil organic carbon, nutrient content and other properties of soil. The tree with crop greatly appreciates the soil organic carbon. Generally higher soil organic carbon and nutrient content under the trees have been observed than the adjacent open sites (Balamurugan et al., 2000). Agroforestry systems are sustainable but many times the huge potential of the systems could not be sustained due to soil health deterioration. There is need to develop sustainable strategies for judicious fertility use in agroforestry system. In tree based cropping system, the competition between crop and tree create the problem of nutrients mining. Simarouba (Simarouba glauca D.C.) is a South American species belonging to Simaroubceae family. In recent times it is becoming popular as a species for commercial plantation of Tree Borne edible Oil. It can grow well in different kind of soil and tolerate drought conditions. It is a suitable Tree Born Oilseed (TBO) of arid and semi arid region of North Gujarat due to their hardness and adoptability on vast areas of waste and marginal lands. The oil is used as edible oil and potential to be used for biofuel. Tree-crop interaction is a complex phenomenon.

\section{Materials and Methods}

Field experiments was carried out during rabi 2010-11 at Research Farm, Centre for Agroforestry, Forage Crops and Green Belt, Sardarkrushinagar Dantiwada Agricultural
University, Sardarkrushinagar (located at $24^{\circ}$ $19^{\prime} \mathrm{N}$ latitude and $72^{\circ} 19^{\prime} \mathrm{E}$ longitude at an altitude of $154.52 \mathrm{~m}$ above mean sea level), Sardarkrushinagar (North Gujarat). The soil was loamy sand in texture low in organic carbon (0.17\%), available nitrogen (159.23 $\mathrm{kg} / \mathrm{ha})$, phosphorus (30.23 kg/ha) and potassium $(187.55 \mathrm{~kg} / \mathrm{ha})$. Experiment was conducted in randomized block design by assigning type of Simarouba plantation of seedling was established at $6.0 \times 4.0 \mathrm{~m}$ spacing during August, 2003. The seed of mustard was sown at a distance of $45 \mathrm{~cm}$ between two rows of simarouba, when the trees were 7 year old. The mustard crop was sown as a intercrop between two rows of simarouba leaving the simarouba basin (a radious of $2 \mathrm{~m}$ ) and as a sole in the open site. The recommended dose of fertilizer of mustard (50: 50: $00 \mathrm{~kg} \mathrm{~N}: \mathrm{P}: \mathrm{K} / \mathrm{ha}$ ) full dose of phosphorus, sulphur and half dose of nitrogen were applied before sowing and remaining half dose of nitrogen was top dressed at 30 DAS. The source of nitrogen, phosphorus and sulphur were Urea, DAP and Gypsum, respectively. Land was prepared during in first week of October while sowing was taken up in last week of October in experimental year. The crop was harvested during first week of March. The plot first irrigation was given immediately after sowing for satisfactory germination and second after 21 DAS for good establishment of the crops remaining irrigations were given as per recommendation. Growth and yield parameters were recorded as per standard procedures. Economics was calculated based on the input and output prices.

\section{Results and Discussion}

Effect of fertilizer levels on intercrop in agri-silviculture system on growth, yield attributes and yield and quality parameters

A perusal of data revealed in mustard crop 
(table 1.1) under simarouba + mustard based agroforestry system, plant height at 60 DAS $(108.30 \mathrm{~cm})$ and at harvest $(195.94 \mathrm{~cm})$, number of branches (9.52), (314.35) of siliqua plant-1, weight (5.78 g), seed, stover and total biomass, oil content and oil yield were significantly recorded maximum under mustard sole with $100 \%$ RDF. Simarouba in comparison to mustard fertilizer application showed pronounced effect of character exhibited marked reduction in values with the increase in shade intensity with simarouba trees. In mustard sole with $100 \%$ RDF (T7) maximum plant height the higher value in open condition and 100\% RDF application due to the suitable environment for the growth and development of plants. This result corroborated with the findings by Pant et al., (2010) and Raj et al., (2010).). In simarouba + mustard sown and sole mustard value of yield attributes increased significantly and increased up to higher fertilizer application. The seed yield of mustard under simarouba increased significant with increasing fertilizer whereas in sole mustard the yield increased significantly up to recommended dose of fertilizer (Deswal and Nandal, 2008). The yield reduction near to tree base can be attributing to low photosynthatically active reduction (PAR). As PAR increased with increasing distance from the tree base production of understory crop also increased. The non significant variation in soil moisture between the area under the tree outside it support that PAR is directly related with production potential of understory of crop moreover, a highly significant positive correlation between PAR and grain yield per meter row also support that the effect of tree shade was more pronounced on yield component compared to vegetative parameters. Although, yield of understory decreased under tree canopy with increasing as of simarouba tree, but increase in wood volume and fruit yield of simarouba fetched more price than loss due to reduction in seed yield of mustard Pandey et al., (2011) and Kaushik et al., (2011). In general, the oil yield has increased with increase in fertilizer dose application and this pattern was observed for both sole and intercropping condition. This may be due to the increase in available $\mathrm{N}, \mathrm{P}$ and $\mathrm{K}$ content of soil and the possible higher uptake of these nutrients Raj et al., (2010).

\section{Effect of fertilizer levels on tree species in agrisilviculture system}

Data presented in table 1.2 revealed that the tree height $(\mathrm{m})$, collar diameter $(\mathrm{cm})$ and diameter at breast height $(\mathrm{cm})$ were found non significant due to different fertilizer levels on tree species in Agrisilviculture system. Increase in fresh and dry fruit weight of simarouba under treatment simarouba + mustard with $100 \%$ RDF (T4) over simarouba + mustard without fertilizer (T2) to the tune of 19.45 and 25.08 per cent, respectively. In simarouba + mustard $100 \%$ RDF was positive influence on fruit yield of simarouba due to there more available of nutrients as per requirement during initial years establishment there by the growth of simarouba was better with these dose Patil et al., (2010). The significantly higher biomass production in above ground level, below ground level and total weight $\left(46.72,9.34\right.$ and $\left.56.06 \mathrm{t} \mathrm{ha}^{-1}\right)$ noted under the treatment of simarouba + mustard with $100 \%$ RDF. Oil content in simarouba dry seed was not influenced significantly due to different fertilizer levels on tree species but oil yield of simarouba tree was significantly influenced due to different fertilizer levels on tree species in agrisilviculture system. Treatment simarouba + mustard with $100 \%$ RDF $\left(\mathrm{T}_{4}\right)$ was found superior by significantly higher oil yield. This might have due to reason being heavy forking and branching ability in the former species than the latter. The reason for such a trend can be attributed to comparative fast growth of simarouba. 
Table.1 Effect of fertilizer levels on plant height $(\mathrm{cm})$ of mustard at 60 DAS and at harvest, branches /plant, siliqua/ plant, test weight, seed stover and total biomass (kg ha-1), oil content (\%) and oil yield (kg ha-1) under simarouba + mustard based agroforestry system

\begin{tabular}{|c|c|c|c|c|c|c|c|c|c|c|c|}
\hline \multirow{3}{*}{ Sr. No. } & \multirow{3}{*}{ Particular of treatments } & \multicolumn{2}{|c|}{$\begin{array}{l}\text { Plant height } \\
(\mathrm{cm})\end{array}$} & \multirow{3}{*}{$\begin{array}{c}\text { Branches } \\
\text { plant }^{-1}\end{array}$} & \multirow{3}{*}{$\begin{array}{l}\text { Siliqua } \\
\text { plant }^{-1}\end{array}$} & \multirow{3}{*}{$\begin{array}{c}(1000- \\
\text { seed) } \\
\mathrm{g}\end{array}$} & \multirow[t]{2}{*}{ Seed } & \multirow[t]{2}{*}{ Stover } & \multirow{3}{*}{$\begin{array}{c}\text { Total } \\
\text { biomass }\end{array}$} & \multirow{3}{*}{$\begin{array}{c}\text { Oil } \\
\text { content } \\
(\%)\end{array}$} & \multirow{3}{*}{$\begin{array}{c}\text { Oil } \\
\text { yield } \\
\left(\begin{array}{c}\mathrm{kg} \mathrm{ha} \\
1\end{array}\right)\end{array}$} \\
\hline & & \multirow{2}{*}{$\begin{array}{c}60 \\
\text { DAS }\end{array}$} & \multirow{2}{*}{$\begin{array}{c}\text { At } \\
\text { harvest }\end{array}$} & & & & & & & & \\
\hline & & & & & & & & $\left(\mathrm{kg} \mathrm{ha}^{-1}\right)$ & & & \\
\hline $\mathrm{T}_{1}$ & Simarouba Sole & - & - & - & - & - & - & - & - & - & - \\
\hline $\mathrm{T}_{2}$ & Simarouba +Mustard without fertilizer & 82.65 & 149.77 & 6.70 & 233.56 & 4.86 & 1588.25 & 3828.50 & 5416.75 & 38.24 & 607.44 \\
\hline $\mathrm{T}_{3}$ & Simarouba + Mustard with 50\% RDF & 88.45 & 160.21 & 7.02 & 248.35 & 5.00 & 1633.75 & 3954.25 & 5588.00 & 39.12 & 639.79 \\
\hline $\mathrm{T}_{4}$ & Simarouba + Mustard with $100 \%$ RDF & 95.20 & 171.36 & 8.78 & 283.75 & 5.40 & 1805.75 & 4424.75 & 6230.50 & 39.65 & 715.02 \\
\hline $\mathrm{T}_{5}$ & Mustard sole without fertilizer & 90.68 & 164.22 & 7.12 & 250.82 & 4.97 & 1641.00 & 3948.00 & 5589.00 & 38.02 & 624.64 \\
\hline $\mathrm{T}_{6}$ & Mustard sole with $50 \% \mathrm{RDF}$ & 102.62 & 183.72 & 8.92 & 295.35 & 5.45 & 1813.25 & 4460.00 & 6273.25 & 39.67 & 722.13 \\
\hline $\mathrm{T}_{7}$ & Mustard sole with $100 \%$ RDF & 108.30 & 195.94 & 9.52 & 314.35 & 5.78 & 1924.00 & 4760.50 & 6684.50 & 39.91 & 768.05 \\
\hline & SEm. \pm & 5.22 & 9.32 & 0.49 & 16.39 & 0.21 & 74.21 & 181.09 & 255.30 & 0.85 & 36.51 \\
\hline & C.D. at $5 \%$ & 15.69 & 28.00 & 1.47 & 49.26 & 0.62 & 223.03 & 544.25 & 767.26 & N.S. & 109.73 \\
\hline & C.V. \% & 11.03 & 10.91 & 12.20 & 12.10 & 7.88 & 8.56 & 9.06 & 8.81 & 4.37 & 10.75 \\
\hline
\end{tabular}


Table.2 Effect of fertilizer levels on tree height $(\mathrm{cm})$, collar diameter $(\mathrm{CD})$ and diameter at breast height (DBH), fresh and dry fruit $\left(\mathrm{kg} \mathrm{ha}^{-1}\right)$ oil content $(\%)$, oil yield $\left(\mathrm{kg} \mathrm{ha}^{-1}\right)$ dry wood weight above and below ground level and total $\left(\mathrm{t} \mathrm{ha}^{-1}\right)$

of simarouba tree (7 years old tree)

\begin{tabular}{|c|c|c|c|c|c|c|c|c|c|c|c|c|c|c|}
\hline \multirow{3}{*}{$\begin{array}{l}\text { Sr. } \\
\text { No. }\end{array}$} & \multirow{3}{*}{$\begin{array}{l}\text { Particular of } \\
\text { treatments }\end{array}$} & \multirow{3}{*}{$\begin{array}{l}\text { Tree } \\
\text { height } \\
(\mathrm{m})\end{array}$} & \multirow{3}{*}{$\begin{array}{l}\mathrm{CD} \\
(\mathrm{cm})\end{array}$} & \multirow{3}{*}{$\begin{array}{r}\mathrm{DBH} \\
(\mathrm{cm})\end{array}$} & \multirow{3}{*}{$\begin{array}{l}\text { Fresh fruit } \\
\left(\mathrm{kg} \mathrm{ha}^{-1}\right)\end{array}$} & \multirow{3}{*}{$\begin{array}{l}\text { Dry } \\
\text { fruit } \\
\left(\mathrm{kg} \mathrm{ha}_{1}\right)^{-}\end{array}$} & \multirow{3}{*}{$\begin{array}{c}\text { Oil } \\
\text { content } \\
(\%)\end{array}$} & \multirow{3}{*}{$\begin{array}{c}\text { Oil } \\
\text { yield } \\
\left(\mathrm{kg} \mathrm{ha}_{1}{ }^{-}\right.\end{array}$} & \multicolumn{6}{|c|}{ Simarouba dry wood weight } \\
\hline & & & & & & & & & \multicolumn{2}{|c|}{$\begin{array}{c}\text { Above ground } \\
\text { level }\end{array}$} & \multicolumn{2}{|c|}{$\begin{array}{l}\text { Below ground } \\
\text { level (Root) }\end{array}$} & \multicolumn{2}{|c|}{$\begin{array}{c}\text { Total } \\
\text { weight }\end{array}$} \\
\hline & & & & & & & & & $\mathrm{kg}$ tree $^{-1}$ & $\mathrm{tha}^{-1}$ & kg tree ${ }^{-1}$ & $\mathrm{tha}^{-1}$ & kg tree ${ }^{-1}$ & $\mathrm{tha}^{-1}$ \\
\hline $\mathrm{T}_{1}$ & Simarouba Sole & 3.72 & 11.52 & 7.99 & 1962.83 & 796.09 & 55.58 & 441.95 & 88.65 & 36.94 & 17.73 & 7.39 & 106.38 & 44.33 \\
\hline $\mathrm{T}_{2}$ & $\begin{array}{l}\text { Simarouba + Mustard } \\
\text { without fertilizer }\end{array}$ & 3.40 & 10.70 & 7.85 & 1860.05 & 721.68 & 55.30 & 399.22 & 70.62 & 29.43 & 14.02 & 5.84 & 84.64 & 35.27 \\
\hline $\mathrm{T}_{3}$ & $\begin{array}{l}\text { Simarouba + mustard } \\
\text { with } 50 \% \text { RDF }\end{array}$ & 3.84 & 11.30 & 8.72 & 2045.01 & 821.11 & 56.81 & 467.19 & 94.89 & 39.54 & 18.98 & 7.91 & 113.87 & 47.45 \\
\hline $\mathrm{T}_{4}$ & $\begin{array}{l}\text { Simarouba + mustard } \\
\text { with } 100 \% \text { RDF }\end{array}$ & 3.98 & 12.48 & 9.45 & 2221.91 & 902.70 & 56.97 & 514.67 & 112.12 & 46.72 & 22.42 & 9.34 & 134.54 & 56.06 \\
\hline $\mathrm{T}_{5}$ & $\begin{array}{l}\text { Mustard sole without } \\
\text { fertilizer }\end{array}$ & - & - & - & - & - & - & - & - & - & - & - & - & - \\
\hline $\mathrm{T}_{6}$ & $\begin{array}{l}\text { Mustard sole with } \\
50 \% \text { RDF }\end{array}$ & - & - & - & - & - & - & - & - & - & - & - & - & - \\
\hline $\mathrm{T}_{7}$ & $\begin{array}{l}\text { Mustard sole with } \\
100 \% \text { RDF }\end{array}$ & - & - & - & - & - & - & - & - & - & - & - & - & - \\
\hline & S.Em. \pm & 0.23 & 0.63 & 0.55 & 73.74 & 30.54 & 1.04 & 21.67 & 8.72 & 3.63 & 1.75 & 0.73 & 10.47 & 4.36 \\
\hline & C. D. at $0.05 \%$ & N.S. & N.S. & N.S. & 226.52 & 93.81 & N.S. & 66.59 & 26.80 & 11.17 & 5.37 & 2.24 & 32.16 & 13.40 \\
\hline & C. V. \% & 14.01 & 12.30 & 14.56 & 8.15 & 8.43 & 4.13 & 10.63 & 21.30 & 21.30 & 21.36 & 21.36 & 21.31 & 21.31 \\
\hline
\end{tabular}


The lowest biomass yield for simarouba might to attribute to heavy leaves shading during that particular period of harvesting the trees for biomass estimation. Similar results were also reported by Giri Rao et al., (2000) and Gill and Gupta (2005).

\section{References}

Balamurugan, J., Kumaraswany, K. and Rajarajan, A. 2000. Effect of Eucalyptus citridora on the physical and chemical properties of soils. J. Indian Soc. Soil Sci., 48(3): 491-495.

Deswal, A.K. and Nandal, D.P.S. 2008. Growth and yield of wheat (Triticum aestivum) under varying levels of irrigation and fertilizer in eucalyptus based Agrisilviculture system. Indian $J$. Agroforestry, 10(1): 10-14.

Gill, A.S. and Gupta, S.K. 2005. Biomass production of trees under semi- arid rainfed agroforestry system. Indian Forester, 591- 594.

Giri, Rao, Joseph, B. and Sreemannarayana, B. 2000. Growth and biomass production of some important multipurpose tree species on rainfed sandy loam soils. Indian Forester, 772- 781.

Kaushik, N., Kumar, K., Kumar, S., Deswal, R. P.S. and Deswal, A.K. 2011. Performance of jatropha (jatropha curacs L.) based agroforestry system under rainfed conditions. Indian J. Agroforestry, 13(1): 96-99.

Pandey, A.K., Gupta, V.K. and Solanki, K.R. 2011. Performance of gram (Cicer arietinum) under neem based agroforestry system in semi -arid region. Indian $J$. Agroforestry, 13(1): 61-66.

Pant, K.S., Mishra, V.K., Sanwal, C. S. and Dinssa, K.U. 2010. Effect of nitrogen and poplar spacing on yield and nutrients content of Taro (Colocasia esculentlenta. Indian J. Agroforestry, 12(1): 18-22.

Patil, S.J., Mutanal, S. M., Shahapurmath, G. and Maheswarappa, V. 2010. Performance of sapota - teak based agroforestry system in hill zone of Karnataka. Indian J. Agroforestry, 12(1): 27-34.

Raj, A.J., Lal, S.B., Daniel, S. and Gowda, V. 2010. Intercropping of lemon grass with poplar (Populous deltoides) in eastern Utter Pradesh. Indian J. Agroforestry, 12(1): 13-17

\section{How to cite this article:}

Narendra Kumar Bajdoliya and Man M.K. 2017. Carbon sequestration and soil properties changes on growth and yield of Simarouba (Simarouba glauca d.c.) based agroforestry system under North Gujarat agro climatic conditions. Int.J.Curr.Microbiol.App.Sci. 6(5): xx-xx. doi: https://doi.org/10.20546/ijcmas.2017.605.237 